TITLE:

\title{
Keratin 19, a Cancer Stem Cell Marker in Human Hepatocellular Carcinoma(Abstract_要旨 )
}

$\operatorname{AUTHOR}(S):$

Kawai, Takayuki

\section{CITATION:}

Kawai, Takayuki. Keratin 19, a Cancer Stem Cell Marker in Human Hepatocellular Carcinoma. 京都大学, 2016, 博士(医学)

ISSUE DATE:

2016-03-23

URL:

https://doi.org/10.14989/doctor.k19551

RIGHT:

許諾条件により本文は2016-07-01に公開 


\begin{tabular}{|c|c|}
\hline 京都大学 & 医 学 ） 氏 名 \\
\hline 論文題目 & $\begin{array}{l}\text { Keratin 19, a Cancer Stem Cell Marker in Human Hepatocellular } \\
\text { Carcinoma } \\
\text { (Keratin } 19 \text { は肝細胞癌における新規癌幹細胞マーカーである) }\end{array}$ \\
\hline $\begin{array}{l}\text { (論文内 } \\
\text { 【目的】 } \\
\text { 存在が明 } \\
\text { 発に強く } \\
\text { は正常組 } \\
\text { は、kers } \\
\text { 細胞癌 } \\
\text { は明らか } \\
\text { 一である } \\
\text { とを本研 } \\
\text { 【方法】 } \\
\text { フローサ } \\
\text { いるか、 } \\
\text { 転換 (ep } \\
\text { 検証した } \\
\text { 組の織学的 } \\
\text { 【結果】 } \\
\text { 陰性細胞 } \\
\text { 分化能を } \\
\text { と比べ有 } \\
\text { 免疫不全 } \\
\text { 能を示し } \\
\text { から、細胞 } \\
\text { する免疫 } \\
\text { いて有意 } \\
\text { TGFbR1 } \\
\text { 【結語】 } \\
\text { K19 陽性 } \\
\text { り、TGF } \\
\text { signalin } \\
\text { に関する }\end{array}$ & 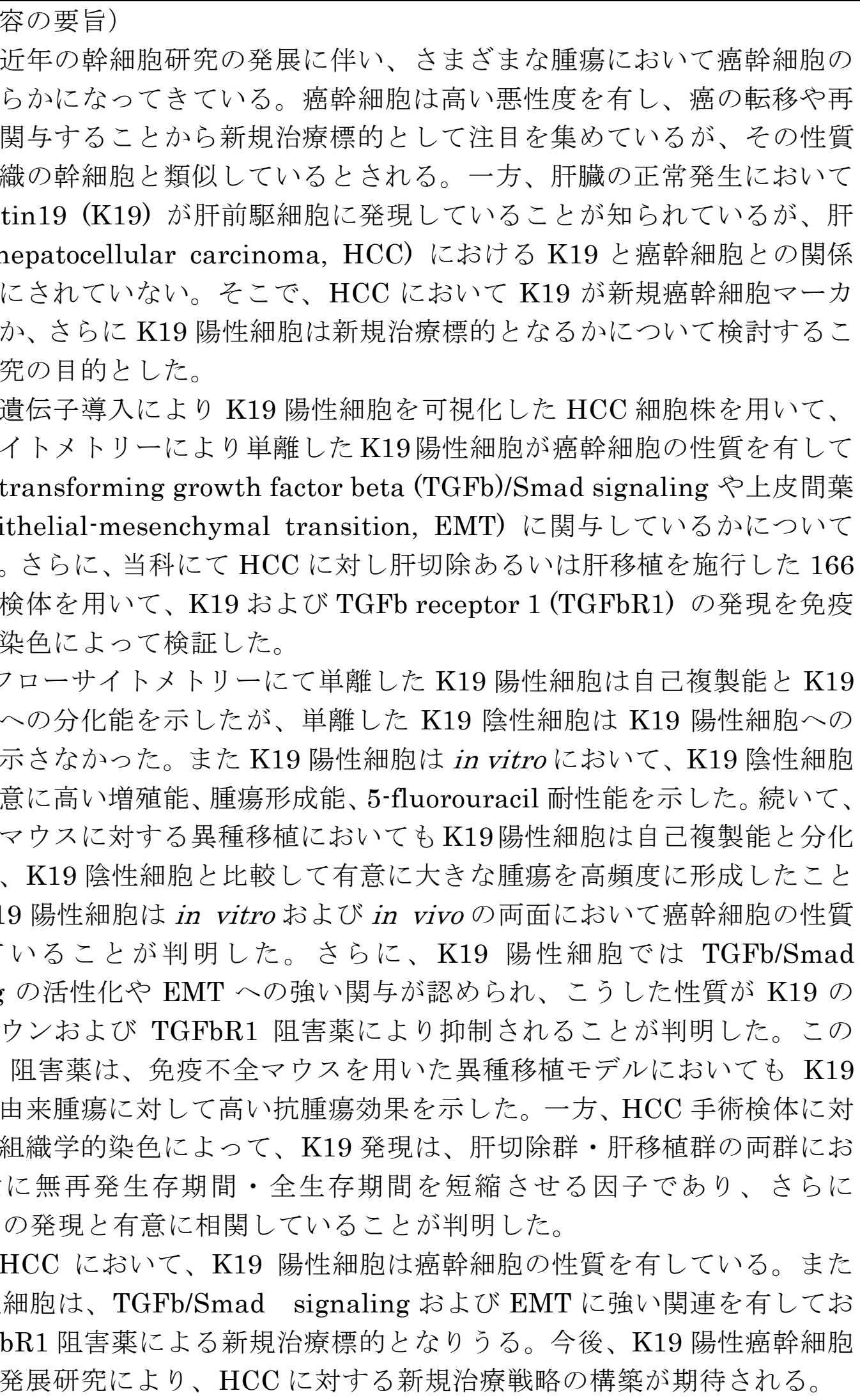 \\
\hline
\end{tabular}

(論文審査の結果の要旨)

肝細胞癌における keratin 19 (K19) と癌幹細胞の関係については明らかにされてい ない。今回申請者は、肝細胞癌において K19 が新規癌幹細胞マーカーとなるか、さらに K19 陽性細胞が新規治療標的となりうるかを検討することを目的とし研究を行った。 遺伝子導入により K19 陽性細胞を可視化した肝細胞癌細胞株を用いて、K19 陽性細胞 と癌幹細胞・TGFb/Smad signaling・上皮間葉転換（EMT）との関連を検討した。 また、166 症例の肝細胞癌手術検体を用いて K19 および TGFb receptor 1 (TGFbR1) の発現を検証した。

K19 陽性細胞は in vitro・in vivoにおいて自己複製能・分化能・高い腫瘍形 成能を示し、TGFb/Smad signaling および EMT と強い関連を示した。さらに、 TGFbR1 阻害薬は K19 陽性細胞に対して高い抗腫瘍効果を示した。一方、肝細 胞癌手術検体において K19 発現は予後不良因子であり TGFbR1 発現と有意な相 関を示した。以上より、K19 は肝細胞癌における新規癌幹細胞マーカーであることが 判明し、K19 陽性細胞はTGFbR1 阻害薬の新規治療標的となりうることが示唆された。 以上の研究は肝細胞癌における K19 と癌幹細胞との関係を明らかにしたものであり、 肝臟病学および腫瘍学に寄与するところが多い。

したがって、本論文溥士 (医学) の学位論文として価値のあるものと認める。なお、本学位 授与申請者は、平成 27 年 10 月 22 日実施の論文内容とそれに関連した試問を受け、合格 と認められたものである。 